\title{
ICT-MECHANISMS OF INTELLIGENT TRANSPORTATION SYSTEM IN TAIPEI CITY AS A SMART CITY
}

\author{
Nurwahyu Alamsyah $^{\mathrm{ab}}$, Tzu-Chuan Chou ${ }^{\mathrm{b}}$ and Tony Dwi Susanto ${ }^{\mathrm{a}}$, \\ ${ }^{a}$ Department of Information Systems \\ Institute of Technology Sepuluh Nopember (ITS) Surabaya, Indonesia \\ ${ }^{\mathrm{b}}$ Department of Information Management \\ NationalTaiwan University of Science and Technology Taipei, Taiwan
}

\begin{abstract}
ICT-enabled service innovation is needed to provide a better service in a smart city. An example of ICTenabled service innovation is intelligent transportation system (ITS) in Taipei City, Taiwan. We developed a eight ICT-mechanisms that support development of service innovation in smart city. This study found that ontime resource control was the most important mechanism. The expectation of this study is make easier another city to develop a smart city's concept.
\end{abstract}

\section{KEYWORDS}

Smart City, ICT Enabled, Service Innovation, Intelligent Transportation System

\section{INTRODUCTION}

The face of city changed. The society preferred to live in the city. It makes cities become a place where all kind of activities converged such as social, economic and environmental. Urbanization causes many important and significant economic, social and demographic transformations (AbuLughod J, Hay R J. 2013 in Chuantao et al. 2015). The characteristic current cities are interconnected by complex system. Many systems integrated like services, technologies, transportations, businesses and utilities to serve their citizens. Those activities increased population growth and urbanization[2].

Complexity in a city can reduced by utilizing the technology. Many cities in the world race to become a smart city by utilizing the technology. In general, the type of smart city is based ontheir abilities to transform using technology [3]-[5]. The concept of smart city has become more popular in scientific literature and international policies. In the future, it is important to understand the concept of smart city and what is the importance for cities to consider key elements [6].

Service is one of important component of smart city. A smart city have to provided its citizens with services via its infrastructure based on information and communication technologies [7]. City need an innovation to deliver better services and being a liveable city. Nevertheless, the smart city concept is too board and not many research revealed service innovation in smart city area.Accordingly, this study aims to explain how ICT-enabled is able to provide service 
innovation. Especially, ICT-enabled of intelligent transportation system as service innovation in smart city area.

\section{LITERATURE REVIEW}

The urbanization, growth and associated problems of modern cities, coupled with the rapid development of new ICT, has enabled us to first visualize the smart cities concept, and now to begin to build smart cities, which is seen as the future form for cities [1]. The recent concept of smart city is including to make better social development. It needs a new approach to mappingcurrent urban problems. Much previous studieshave emphasized a smart city in many definitions [8].

A smart city has ability to provide advanced service innovation to their citizens by use ICT systems. It will be improve the quality of their life. Piro proposed a platform advanced information centric based ICT services of a smart city [9].Nowadays, many cities implemented a new innovation service to provide competitiveness within their city [7]

To be smarters, city should provide service innovation via internet-based applications. It is required to ensure and manage all kind of service innovation work properly [10]. Intelligent transportation systems, environmental issues and participatory governance are needed toward a smart city [11].Many definitions of smart cities exist. The terminology of smart city is still not consistent and there is no fixed definition about smart city [6]. Many previous research has problem to define and categorize smart cities [12]. There is no standarization about definision of a smart city and many cities say that their cities are smart without having a spesific standar [13].

The term 'smart city' appeared for the first time in the early 1990s, and researchers have emphasized technology, innovation and globalization in the process of urbanization [14]. As purposed by Giffinger and Pichler-Milanović (2007) The smart city has six main dimensions: a smart economy, smart mobility, a smart environment, smart people, smart living, and smart governance. Smart cities have attracted great attention since 2008, with the launch of IBM's Smarter Planet project [15]. Batty et al. (2012)defined that ICT was integrated using new digital technologies to coordinate traditional infrastructures. The stakeholders have not clear understanding about the definitions of smart cities [1].

In addition, other countries are also driving and implementing smart city technologies and applications such as Manchester, Berlin, Barcelona, Edinburgh, Bath and Amsterdam. Many of them have a similar approach and in addition to create a better life within the city [17][19].Taiwan is one of country that focus build smart city system. They already implemented smart transportation over the past decade. Since then the government has proclaimed it will definitely develop public transportation [20]. In addition, Taipei city provides ubiquitoes free WiFi for their citizens, Chou and Huang (2012) explained M-Taipei initiative is one of the first major cities in the world to roll out its own public wireless Internet service, with the city government - in cooperation with private companies - leading the way. For example, New York implemented a good digital strategy by respect to resources, needs, and priorities. They used technology in publis service and involve a intelligent plan to encourage their digital potential for their core areas: access, open government, engagement, and industry[22]. 
In the previous research, smart city has some component to describe what is the requirements if a city want to become smarter city. Giffinger and Pichler-Milanović (2007) developed six typology of smart city function such us smart economy, smart people, smart governance, smart mobility, smart environment, and smart living (see Figure 1).

The six typology from Giffinger was develop further by Chuantao et al. (2015) by for classification of smart city pplication domains. The objective of this classification is to avoid the positioning of an application or project into a subclass that may cause the isolation of an integrated system or application. The classification helps investors and designers of smart cities to better understand their project's domain coverage and potential benefit. The city is not enough only provide good service for citizen, need a innovation to manage complexity caused by urbanization. To be smarter, city should deliver service innovation to make sure their city is liveable. To introduce and improve of existing services in the various contexts is needed service innovation to become a important references. J.H. Lee and Hancock (2012) divided service innovation into sub-dimension: service diversity and service integration.Den Hertog (2000) proposed service concept, client interface, service delivery system and technology as four dimensional model of service innovation. This model was one of idea a in knowledge-based economy [23].

Smart city is related to certain kind of service innovation. This topic is becoming interest for improve quality of life, global competitiveness, urban development and sustainable socioeconomic. All of them are challenges for the city to present their concept as a smart city [24].Service innovation is needed as a good references to provide a better service like dynamic information, interneal service innovation and customers technologies [25]. ICT-enabled services innovation have become the main driver of productivity and economic growth. ICT-enabled service innovation is a significant way to provide ICT services [26]. ICT has become main driver to intelligent transportation system that has been defined and measured by using ICT-enabled's components (e.g radio-frequency identification (RFID), global positioning system (GPS), sensors, Wi-Fi, cameras, smart cards, etc).

Table1. Classification of smart city application domains

\begin{tabular}{|c|c|c|}
\hline Domain & Sub domain & Description \\
\hline $\begin{array}{l}\text { Government } \\
\text { (more } \\
\text { efficient) }\end{array}$ & $\begin{array}{l}\text { E-government, Transparent } \\
\text { government, Public service } \\
\text { Public safety, City monitoring } \\
\text { Emergency response }\end{array}$ & $\begin{array}{l}\text { Improving the internal and external efficiency of the government; } \\
\text { enabling citizens and other relevant organizations to access official } \\
\text { documents and policies; ensuring that public services work efficiently; } \\
\text { monitoring and managing public safety; responding quickly and } \\
\text { effectively in emergency situations. }\end{array}$ \\
\hline $\begin{array}{l}\text { Citizen } \\
\text { (happier) }\end{array}$ & $\begin{array}{l}\text { Public transport, Smart traffic } \\
\text { Tourism, Entertainment, } \\
\text { Healthcare, Education, } \\
\text { Consumption, Social cohesion }\end{array}$ & $\begin{array}{l}\text { Traveling and moving more efficiently; accessing contextualized, } \\
\text { precise, real-time information in daily life; high-quality essential public } \\
\text { services such as education, healthcare and sport; enriching spare time } \\
\text { activities, communicating and sharing more with others. }\end{array}$ \\
\hline $\begin{array}{l}\text { Business } \\
\text { (more } \\
\text { prosperous) }\end{array}$ & $\begin{array}{l}\text { Enterprise management, } \\
\text { Logistics, Supply chain, } \\
\text { Transaction, Advertisement, } \\
\text { Innovation, Entrepreneurship, } \\
\text { Agriculture }\end{array}$ & $\begin{array}{l}\text { Improving inter management efficiency and quality; using more } \\
\text { efficient logistics and supply chain platforms and methods; advertising } \\
\text { more widely and accurately; expanding trade partners and customers; } \\
\text { facilitating entrepreneurship and investment; upgrading the business } \\
\text { activity in a city, such as production, commerce, agriculture and } \\
\text { consulting; fostering innovation. }\end{array}$ \\
\hline $\begin{array}{l}\text { Environment } \\
\text { (more } \\
\text { sustainable) }\end{array}$ & $\begin{array}{l}\text { Smart grid, Renewable energy, } \\
\text { Water management, Waste } \\
\text { management, Pollution control, } \\
\text { Building, Housing, Community, } \\
\text { Public space }\end{array}$ & $\begin{array}{l}\text { Delivering more sustainable, economic and secure energy and water } \\
\text { supplies by taking into account citizens' behavior; using more green or } \\
\text { renewable energy; recycling and treating waste efficiently and safely; } \\
\text { reducing and preventing pollution in the city; offering mobility, } \\
\text { telecommunication, information and all other facilities in different city } \\
\text { spaces. }\end{array}$ \\
\hline
\end{tabular}


Many cities in the world compete to be the smartest. One of important component from smart city is smart transportation. The city should have intelligent transportation system if want to be smart city. Previous research described intelligent transportation system in many term. In Japan, intelligent transportation system is know as AMTICS and RACS, but in European people, they called intelligent transportation system by Prometheus. But the purpose is related [27].

However, Lee wrote that intelligent transportatition should integrate all system represent a typical human-centered and highly complex dynamic that integrate communications, sensing, traffic management, information technology and control[28]. The idea about transport system smarter is not something new, this is a strategy to present smart technologies in urban transport system[29]. The functions of the complete intelligent transportation system demonstration system include intelligent transportation system traffic surveillance and information center, intelligent transportation system's vision systems, intelligent traveler information and safety assistance, spoken man-machine interfaces, intelligent vehicle control and safety assistance, automated driving smart car, advanced communication networks, Ad hoc inter-vehicle video conference, and smart agent-based travel information [28]. to improve the connection among different tranportation systems. By providing real time traffic information, intelligent transportation system enhances

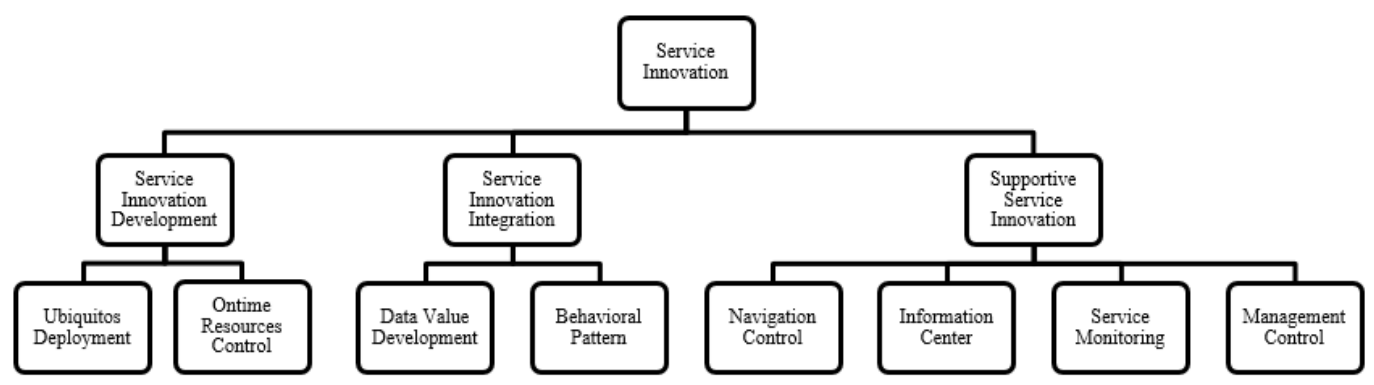

Figure 1. The Research Framework

the safety, efficiency and comfy to use public transportation system. Obviously, it will minimizing the impact of traffic infrastructure on the environment.

Furthermore, while the advances in information and communication technology are very fast, the transformation of transport systems and infrastructures tends to take a long time [30]As introduced above, intelligent transportation systems integrates advanced computers, information, electronic communications and sensor technologies, intelligent transportation system is also ableimprove the connection among different tranportation systems. By providing real time traffic information, intelligent transportation system enhances the safety, efficiency and comfy to use public transportation system. Obviously, it will minimizing the impact of traffic infrastructure on the environment.

\section{METHODOLOGY}

We selected Taipei City as a case of smart city, Taipei is one of smartest city in the world. The American media BuzzFeed has ranked Taipei as one of the 53 beautiful cities.Taipei also scores high in the fields of cuisine and transportation, for example its night market snacks which garnered CNN coverage and the YouBike bike rental system that has received positive reviews by 
travel magazine Global Traveler.Many cities in the world adjusted smart city concept to solve their problems. In Chicago,Argonne National Labora- tory computer scientist Charlie Catlett planned city wide installation of at least 500 sensor-packed boxes to measure temperature, precipitation, humidity, air quality, and pedestrian flow [31].

Taipei is very serious to provide a comfortable service to their citizens. The last urban planning project for Taipei was released in 1930, therefore a new one is urgently needed and also devise a comprehensive long-term plan for city development as seen in metropolises like Tokyo, Seoul, London, and Amsterdam. Nowadays, Taipei already built their service innovations for being a smart city. Several services use technology to make their citizens more comfortable, safe and healthy. In this city, we can easy to get Wi-Fi signal. Most of locations have installed Wi-Fi router, this service named by Taipei-Free. Furthermore, Taipei also has installed the "Fiber-ToThe-Home" optical fiber network program, as well as the triple play in telecommunication to enhance municipal cloud services. Another ICT-enabled service innovations that have installed such usopen data, intelligent traffic, and the role of ICT in upholding public safety. Taipei's Mayor stressed that any administrative envisioning of where Taipei will be heading should take into account the factors of time and space as well as the nation of capital as a living circle. (Department of Information Technology, Taipei City Government, 2016).

In addition to direct observations, we studied hundreds previous papers about smart city. The tren rise is in line with smart city concept that popular in several cities in the world. From a hundreds previous paper, we found that researchers studied more about technical issue such as internet, WiFi, GPS, radio signal, etc. It was not many paper that discussed about management process in smart city. Therefore, we narrowed down the scope of smart city concept. Focus in this research is about ICT-enabled service innovation in smart city area. If we talked about service in smart city, it will be closely related with public transportation systems.

Smart city was not only about technology, we interested to know what is the management process inside, how is a smart city starts develop the concept, What ICT components were used to be smarter city? What kind of innovation are able to develop using technology?

After we studied a hundreds previous paper, this study was more focus on ICT components in intelligent transportation systems that has illustrated at Figure 3. Based on previous papers and direct observation in public tranportation systems in Taipei, then we collected ICT components in intelligent transportation system. From those components, we created mechanisms that using technology, we called by ICT-enabled mechanisms as ilustrates Figure 1. Furthermore, we created questionnaire and we sent to 24 experts in Taipei, Taiwan by email. We receivedfive experts from Taipei.We analyzed the data using analytic hierarcy process and we got the rankings of the most important mechanisms according the experts.

In this study, we used analytic hierarchy process (AHP) to know the ranking of ICT-enabled mechanism. The AHP is most useful where teams of people are working on complex problems, especially those with high stakes, involving human perceptions and judgments, whose resolutions have long-term repercussions (Bhushan, Navneet; Kanwal Rai, 2004). It has unique advantages when important elements of the decision are difficult to quantify or compare, or where communication among team members is impeded by their different specializations, terminologies, or perspectives. 
AHP is a research method to support rational decision making on several qualitative factors (Saaty, 1971). AHP is a highly out-standing management tool for complex multi-criteria decision problems and was developed as a methodology that can present flexible solution on qualitative and quantitative problems.

First, several criteria are suggested to accomplish desired target and set factors for each of the criteria. Factors for each criteria and sub-factors must be correlated. Once each factor and subfactor is organized in stratified order, the establishment of overall stratified structure for the target is completed. One, then, simply needs to carry out mutual pair-wise comparison for each of the factors that have been converted into numerical scale for each level in accordance with stratified structural process for which establishment has been completed.Comparison of criteria must be executed for the subject of comparison and the total number of comparisons is $n(n-1) / 2$. If the score for each factor has similar weight in terms of level of preference between subjects of comparison, it will be expressed in words such as same or with number 1.Scores with scale of 19 (1: equal importance; 9: absolute importance) recommended by Saaty was referred to. Each criteria/measures is quantified by finding the value of maximized Eigen value, consistency index (CI) and consistency ratio (CR). CR index in AHP is used in order to maintain consistency in decision making of the responder. CR can be defined as follows:

$$
\mathrm{CR}=\frac{\mathrm{CI}}{\mathrm{RI}}
$$

$\mathrm{CI}$ is the consistency index and RI is the random index.CI can be defined as follows:

$$
\mathrm{CI}=\frac{\lambda \operatorname{Max}-n}{n-1}(2)
$$

RI is the 9-point scale consistency index generated through pair wise comparison as showed on Table 2. If the CR value is too high, then it is deemed that there is no reliability in the decision on the chosen preference. Saaty (1980) and Millet and Saaty (2000) stated that, in general, CR value in the range of $0.10-0.20$ is appropriate. If the CR value exceeds 0.2 , then repetitively carry out the same procedure through feedback until the maximum Eigen value, CI, and CR value are satisfactory, or otherwise remove the outcome of such response.

\section{PRESENTATION OF FINDINGS}

This section presents the background information about intelligent transportation system in Taipei City, Taiwan. In early 1990, Taiwan began to build their public transportation, various transportation mode have established for provide convenient service to their citizens. In 1996, The Taipei MRT System, popularly known as the Taipei Metro has opened to significantly facilitated transportation in the city.

In the above literature survey, direct observations and also data from official website of department of transportation Taipei city, there are ICT components in intelligent transportation system. Based on ICT components of intelligent transportation system, as shown in Table 3, we purposed ICT-enabled mechanism and service innovation in smart city area. 


\subsection{Ubiquitous Deployment}

Ubiquitous deployment is mechanism that contains basic ICT components. Cities are smart if most of ICT components were deployed to the whole city. For instance, how many monitoring cameras, how many locations already installed free $\mathrm{Wi}-\mathrm{Fi}$, and all that. In Taipei city, we will easy to get facilities based on ICT for free. Begin from free Wi-Fi spread in the whole city, smart payment using Easy card, monitoring cameras in everywhere, self-service station for rental bike and mass rapit transit (MRT). In securty issue, RFID tags and reader for security in addition to the manual keys.

\subsection{Ontime Resource Control}

This mechanism is aims to ensure all resources in smart city works ontime. By using this mechanism, citizens in smart city are easier to manage and make itinerary. This Mechanism is related with numbers of vehicles, road condition, and estimate mileage. Cities should harness data statistic and technology to estimate the real time, make it easier to provide comfort for the citizens.

\subsection{Data Value Development}

Data value development will make public easier to make some complement applications for support smart city. Developers in smart city use open data to access all data that related with intelligent transportation systems. This mechanism is require smart city to open their data, allocate API for developers, statistics and others data.

\subsection{Behavioral Pattern}

When the city smarter, most of ICT components work properly, a smart city is required to always upgrade their services. One of them is increase a speed of services. To realize that, the city need a pattern that appeared when citizens use smart city service. Citizens behavioral pattern will visible use GPS or data mining, then illustrates in the form of visual.

Table 2. RI Value

\begin{tabular}{|c|c|c|c|c|c|c|c|c|c|c|c|c|}
\hline Row & 1 & 2 & 3 & 4 & 5 & 6 & 7 & 8 & 9 & 10 & 11 & 12 \\
\hline RI & 0 & 0 & 0.52 & 0.89 & 1.11 & 1.25 & 1.35 & 1.4 & 1.45 & 1.49 & 1.51 & 1.54 \\
\hline
\end{tabular}

Table3. Components and Mechanism in Service Innovation

\begin{tabular}{|c|c|c|}
\hline ICT Components & ICT-enabled Mechanism & Service Innovation \\
\hline $\begin{array}{l}\text { Internet connection, ubiquitous Wi-Fi, wireless communication, cameras, } \\
\text { vehicle sensors, self service station, smart payment cards, RFID tags, nad } \\
\text { RFID readers. }\end{array}$ & Ubiquitous Deployment & \multirow{2}{*}{$\begin{array}{l}\text { Service } \\
\text { Development }\end{array}$} \\
\hline $\begin{array}{l}\text { Traffic behaviour statistic analysis, district closed-circuit television cameras } \\
\text { (CCTV) systems, monitoring of particular road section, and analysis } \\
\text { commuting time. }\end{array}$ & Ontime Resource Control & \\
\hline Open data and API for developers. & Data Value Development & \multirow{2}{*}{ Service Integration } \\
\hline Data mining, data visualization, and GPS data traces of human movement. & Behavioral Pattern & \\
\hline Digital maps, GPSs, and realtime traffic analysis. & Navigation Control & \multirow{4}{*}{$\begin{array}{l}\text { Supportive Service } \\
\text { Innovation }\end{array}$} \\
\hline Cloud guide system, official website, social media, and mobile apps. & Information Center & \\
\hline Realtime information system, voice-call service, and back-end management. & Service Monitoring & \\
\hline Control center, logistic and maintenance management. & Management Control & \\
\hline
\end{tabular}


International Journal of Computer Science \& Information Technology (IJCSIT) Vol 8, No 3, June 2016

It will easier to discover the pattern how citizens use services. If we are able to know the pattern, it will make easier to escalate the speed of service by serve a better public transportation.

\subsection{Navigation Control}

This mechanism will controlling all kind of vehicles: personal vehicle or vehicle for public tranportation. Smart city has to use technology as digital maps and GPS for analyze realtime traffic volume. By using those technologies and study extensively, smart city is able to reduce congestion. This is a major problems and also common issues in densely populated cities. In Taipei, inside the city bus has already embedded GPS, it makes the city bus is able to announce where is the next destination. This system is connected with alert system using LED text displays. Taipei City has Advanced vehicle control and safety service (AVCSS) that mainly used in vehicle manufacturing, for example, anti-collision warning system. When the front or rear is too close to another vehicle, a warning sound reminds the driver to keep a safe distance. They also have the vulnerable individual protection service (VIPS).Audio signals have been set up at major intersections in Taipei City. Bike lanes and pedestrian-only lanes will be introduced and displayed in further detail later.

\subsection{Information Center}

Information center is one of the most important mechanism but it is often forgotten. This mechanism will be one of major priority for provide facilties in a smart city. Every citizens or tourists will looking for infomation about public transportation services when they want to go to some places. A smart city should use technologies to give that facilities. Several ways to do is allocate official website, offical social media account, mobile apps or cloud guide system. Those facilities will make citizens or tourists enjoy to visit that smart city.

\subsection{Service Monitoring}

The quality of service will decrease if there is no sustainable monitoring. This mechanism will assign ease of use to smart city to observe services on the whole. By using real time information systems, back-end management, or even voice-call service, a smart city is able to monitoring every services.Smart city obtains information about bad service, pretty good service or excellent service. Therefore, service is able to continue to developed following the existing conditions. Youbike is one of mass transportation service in Taipei that use back-end management to enhance their service run properly.

\subsection{Management Control}

Management contol in this context is mechanism that require smart city to always do controlling to the existing management. This mechanism is able to the city maintain the quality of public transportation service and make it more stable. In addition, this mechanism will make easy smart city to improve, increase, or cut down the existing services. As city bicycle schemes spread around the globe, Taiwan, a keymanufacture of the world's bicycles for many years, has fir- 
mlyembraced the trend, integrating information communication technology to enhance the soft power exertedby bicycle systems.By bringing together bicycle manufacturers, systemplatform operators, and logistics and maintenance providers, rentalstations have been set up throughout Taipei, providing a 24/7,year-round mass transportation tool. User registration and rental procedureshave been simplified, and a smart bicycle management system hasbeen set up through backend cloud computing.

Table4. Result of Analysis

\begin{tabular}{|c|c|c|c|c|c|c|c|c|c|}
\hline & $\begin{array}{c}\text { Ubiquitous } \\
\text { Deployment }\end{array}$ & $\begin{array}{c}\text { Ontime } \\
\text { Resource } \\
\text { Control }\end{array}$ & $\begin{array}{c}\text { Data Value } \\
\text { Development }\end{array}$ & $\begin{array}{c}\text { Behavioral } \\
\text { Pattern }\end{array}$ & $\begin{array}{c}\text { Navigation } \\
\text { Control }\end{array}$ & $\begin{array}{c}\text { Information } \\
\text { Center }\end{array}$ & $\begin{array}{c}\text { Service Moni- } \\
\text { toring }\end{array}$ & $\begin{array}{c}\text { Management } \\
\text { Control }\end{array}$ & $\begin{array}{c}\text { Priority } \\
\text { Vector }\end{array}$ \\
\hline $\begin{array}{c}\text { Ubiquitous Deploy- } \\
\text { ment }\end{array}$ & 1.00 & 0.50 & 1.60 & 10.58 & 3.46 & 6.11 & 0.63 & 2.07 & 0.21 \\
\hline $\begin{array}{c}\text { Ontime Resource } \\
\text { Control }\end{array}$ & 2.00 & 1.00 & 17.89 & 16.73 & 1.73 & 2.45 & 1.10 & 2.65 & 0.25 \\
\hline $\begin{array}{c}\text { Data Value Devel- } \\
\text { opment }\end{array}$ & 0.62 & 0.06 & 1.00 & 0.58 & 0.06 & 0.09 & 0.09 & 0.50 & 0.03 \\
\hline Behavioral Pattern & 0.09 & 0.06 & 1.73 & 1.00 & 0.14 & 0.29 & 0.19 & 1.00 & 0.03 \\
\hline Navigation Control & 0.29 & 0.58 & 15.49 & 7.07 & 1.00 & 2.00 & 1.41 & 6.71 & 0.18 \\
\hline Information Center & 0.16 & 0.41 & 11.62 & 3.46 & 0.50 & 1.00 & 0.75 & 2.45 & 0.10 \\
\hline Service Monitoring & 1.41 & 0.91 & 10.95 & 5.16 & 0.71 & 1.34 & 1.00 & 3.46 & 0.16 \\
\hline Management Control & 0.48 & 0.38 & 2.00 & 1.00 & 0.15 & 0.41 & 0.29 & 1.00 & 0.05 \\
\hline & & & & & & $\lambda$ Max $=9.49$ & $\mathrm{CI}=0.21, \quad \mathrm{CR}=0.15$ \\
\hline
\end{tabular}

\section{DISCUSSION OF FINDINGS}

The above research issues the ICT-enabled service innovation in smart city area. After we collected and analyzed the data from experts, we got the results: what is the most important ICTmechanisms. The result illustrates in Table 4 is the most important ICT-mechanism. Ontime resource control is the most important mechanism in Taipei because their citizens have many activities everyday. This mechanism got the highest score than other: 0.25 . Most of Taipei citizens are able to move rapidly from one district to another district even city within one day. Taipei citizens not only need availability public transportation, but also need fixed transportation system for make sure their activities on time along days. Behavioral pattern score 0.02. This is ilustrates that citizens did not care so much about the importance of behavioral pattern. Eventhough, this mechanism is important to deliver better service in the future based on pattern of behavior Taipei citizens.

Information center is not too important today due to it has been established. The rankings ICTenabled mechanism according to the most important in Taipei is ontime resource control, ubiquitous deployment, navigation control, service monitoring, information center, management control, behavioral pattern, and data value development.

For this case, Taipei was more concern about how to make all of resource be ontime to serve their citizens.Even though Taipei already established the intelligent transportation system, ubiquitous deployment still important to make all of part in Taipei connected each other.Ubiquitous deployment mechanism is the second important below ontime resource control mechanism. The 
third important mechanism is navigation control to make sure most of their public transportation can be access from multi platform using digital maps, GPS, and realtime traffic analysis. Furthermore, navigation control was also important to helpful to control the public transportation if there are some congestion in some places around Taipei. Service monitoring and information center in Taipei city were good condition.

They only need to improve and increasing the efficiency. Management control, behavioral pattern and data value development are the last mechanism from Taipei City. Those mechanism were in the lowest rankings, but it does not mean those were not useful. A city should to consider the most important mechanism if want to become smarter city, depend on their recently situation.

\section{CONCLUSION AND IMPLICATIONS}

The city around the world often confused what should they do to be smarter city. In this study, we provide eight ICT-mechanisms for develop intelligent transpor-tation system. Those mechanisms were inspired by smart city concept in Taipei City and previous papers about smart city around the world. Many previous research deliver another theory to develop the whole concept, technical issue, saving energy, governance and others. But, not many research wrote about ICT-enabled in smart city. It will be implication complements the another theory for this research area, and also will be useful for practise issue, especially for one of the most important service innovation in smart city: intelligent tranportation systems. Those mechanisms have the rangkings, but actually, all of mechanism have interrelation among other mechanism. A city should think about the whole mechanism.If they want to develop by the most important mechanism, it can use this term. This study also has some limitations.The paper discuses eight ICT-enabled mechanism for develop intelligent transportation system. Although there are other mechanisms such as quality of life, Society of change, etc. In future these aspects need to be addressed to.

\section{REFERENCES}

[1] Y. I. N. Chuantao, X. Zhang, C. Hui, W. Jingyuan, C. Daven, and D. Bertrand, "A literature survey on smart cities," vol. 58, no. October, pp. 1-18, 2015.

[2] P. Neirotti, A. De Marco, A. C. Cagliano, G. Mangano, and F. Scorrano, "Current trends in Smart City initiatives: Some stylised facts," Cities, vol. 38, pp. 25-36, 2014.

[3] R. Giffinger and N. Pichler-Milanović, "Smart Cities: Ranking of European Medium-Sized Cities," no. $2007,2007$.

[4] G. C. Lazaroiu and M. Roscia, "Definition methodology for the smart cities model," Energy, vol. 47, no. 1, pp. 326-332, 2012.

[5] J. H. Lee, M. G. Hancock, and M.-C. Hu, "Towards an effective framework for building smart cities: Lessons from Seoul and San Francisco,” Technol. Forecast. Soc. Change, vol. 89, pp. 80-99, 2014.

[6] V. Albino, U. Berardi, and R. M. Dangelico, "Smart Cities: Definitions, Dimensions, Performance, and Initiatives,” J. Urban Technol., vol. 22, no. 1, pp. 3-21, 2015.

[7] J. Lee and H. Lee, "Developing and validating a citizen-centric typology for smart city services," Gov. Inf. Q., vol. 31, pp. S93-S105, 2014.

[8] S. Alawadhi, A. Aldama-Nalda, H. Chourabi, J. R. Gil-Garcia, S. Leung, S. Mellouli, T. Nam, T. a. Pardo, H. J. Scholl, and S. Walker, "Building understanding of smart city initiatives," Lect. Notes Comput. Sci. (including Subser. Lect. Notes Artif. Intell. Lect. Notes Bioinformatics), vol. 7443 LNCS, pp. 40-53, 2012.

[9] G. Piro, I. Cianci, L. A. Grieco, G. Boggia, and P. Camarda, "Information centric services in Smart Cities,” J. Syst. Softw., vol. 88, pp. 169-188, 2014. 
International Journal of Computer Science \& Information Technology (IJCSIT) Vol 8, No 3, June 2016

[10] G. Kuk and M. Janssen, "The Business Models and Information Architectures of Smart Cities," J. Urban Technol., vol. 18, no. 2, pp. 39-52, 2011.

[11] N. Bicocchi, A. Cecaj, D. Fontana, M. Mamei, A. Sassi, and F. Zambonelli, "Collective awareness for human-ICT collaboration in smart cities," Proc. Work. Enabling Technol. Infrastruct. Collab. Enterp. WETICE, pp. 3-8, 2013.

[12] A. Ponting, "High-Tech Urbanism: The Political and Economic Implications of the Smart City," 2013.

[13] R. G. Hollands, "Will the real smart city please stand up?," City, vol. 12, no. 3, pp. 303-320, 2008.

[14] S. R. W. Gibson D V, Kozmetsky G, "The Technopolis Phenomenon: Smart Cities, Fast Systems, Global Networks," Rowman Littlef. Publ., 1992.

[15] S. J. Palmisano, "A Smarter Planet: The Next Leadership Agenda," no. IBM, 2008.

[16] M. Batty, K. W. Axhausen, F. Giannotti, A. Pozdnoukhov, A. Bazzani, M. Wachowicz, G. Ouzounis, and Y. Portugali, "Smart cities of the future," Eur. Phys. J. Spec. Top., vol. 214, no. 1, pp. 481$518,2012$.

[17] S. H. Lee, J. H. Han, Y. T. Leem, and T. Yigitcanlar, "Towards Ubiquitous City: Concept, Planning, and Experiences in the Republic of Korea," Knowledge-Based Urban Dev. Plan. Appl. Inf. Era, pp. 148-170, 2008.

[18] T. Nam and T. a. Pardo, "Conceptualizing smart city with dimensions of technology, people, and institutions," Proc. 12th Annu. Int. Digit. Gov. Res. Conf. Digit. Gov. Innov. Challenging Times dg.o '11, p. 282, 2011.

[19] J. H. Lee, R. Phaal, and S.-H. Lee, "An integrated service-device-technology roadmap for smart city development," Technol. Forecast. Soc. Change, vol. 80, no. 2, pp. 286-306, 2013.

[20] L. W. Lan, M.-T. Wang, and A. Y. Kuo, "Development and Deployment of Public Transport Policy and Planning in Taiwan," Transportation (Amst)., vol. 33, no. 2, pp. 153-170, 2006.

[21] T. C. Chou and M. Y. Huang, "Understanding the roles of business ecosystems in large public IT infrastructure project development: The case of M-Taipei,” Int. J. Inf. Manage., vol. 32, no. 1, pp. 88-92, 2012.

[22] T. City Of New York, "Road Map for the Digital City: Achieving New York City's Digital Future," City, vol. 2, no. 7. 2011.

[23] S. Durst, A.-L. Mention, and P. Poutanen, "Service innovation and its impact: What do we know about?,” Investig. Eur. Dir. y Econ. la Empres., vol. 21, no. 2, pp. 65-72, 2014.

[24] L. Errichiello and A. Marasco, "Open Service Innovation in Smart Cities: A Framework for Exploring Innovation Networks in the Development of New City Services," Adv. Eng. Forum, vol. 11, pp. 115-124, 2014.

[25] K.-H. Chen, C.-H. Wang, S.-Z. Huang, and G. C. Shen, "Service innovation and new product performance: The influence of market-linking capabilities and market turbulence," Int. J. Prod. Econ., vol. 172, pp. 54-64, 2016.

[26] A. Rai and V. Sambamurthy, "Editorial notes-the growth of interest in services management: Opportunities for information systems scholars," Inf. Syst. Res., vol. 17, no. 4, pp. 327-331, 2006.

[27] a Garcia-Ortiz, S. Amin, and J. Wootton, Intelligent Transportation Systems Enabling Technologies, vol. 22, no. 4-7. 1995.

[28] T. T. Lee, "Research on Intelligent Transportation Systems in Taiwan," Proc. 27th Chinese Control Conf. CCC, no. 91, pp. 18-23, 2008.

[29] A. K. Debnath, H. C. Chin, M. M. Haque, and B. Yuen, "A methodological framework for benchmarking smart transport cities," Cities, vol. 37, pp. 47-56, 2014.

[30] K. M. Weber, B. Heller-Schuh, H. Godoe, and R. Roeste, "ICT-enabled system innovations in public services: Experiences from intelligent transport systems," Telecomm. Policy, vol. 38, no. 5-6, pp. 539-557, 2014.

[31] G. Mone, "The new smart cities," Commun. ACM, vol. 58, no. 7, pp. 20-21, 2015. 
Nurwahyu Alamsyahis adouble-degree master student of Information Systems in Institute of Technology Sepuluh Nopember (ITS), Indonesia and Department of Management Information in National Taiwan University of Science and Technology. Before doing master degree, He was a contract-lecturer in University of Trunojoyo Madura. He is currently doing a research in smart city area and digital enablement.

Tzu-Chuan Chou is aprofessor and chairman, Department of Information Management, National Taiwan University of Science and Technology, Taiwan. He received his Ph.D from Warwick Business School, the University of Warwick, UK in 1999. His research interests include IT outsourcing, IT governance, knowledge management, E-government and digital enablement. He has papers published in a number of international journals.

Tony Dwi Susanto is a lecturer at Information Systems Department, Institute of Technology Sepuluh Nopember (ITS), Indonesia. He received his Ph.D at School of Computer Science, Engineering, and Mathematics (CSEM), the Flinders University of South Australia. Before joining the Ph.D program, he has held positions as visiting researcher at CSEM-South Australia and King Saud University-Saudi Arabia, and a representative of Indonesia at IATSS ForumJapan. His research interests include technology adoption, e-government and mobile technolo-

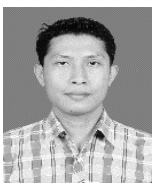
gy. His papers in the fields of e-government and mobile services have been published and presented at several international conferences and journals. 